\title{
Pengabdian Kelompok Ternak Sapi Melalui Perbaikan Pakan di Kabupaten Sambas
}

\section{Duta Setiawan}

Program Studi Peternakan Fakultas Pertanian, Universitas Tanjungpura Pontianak Email: duta.setiawan@faperta.untan.ac.id

\begin{tabular}{ll}
\hline Article History: & Abstrak: \\
Received: November & Program pengabdian masyarakat ini bertujuan \\
Revised: November & untuk memperbaiki manajemen pakan, dan \\
Accepted: Desember & meningkatkan BCS body condition score) \\
Available online: & sapi. Kegiatan ini dilaksanakan selama empat \\
Desember & bulan di Desa Sungai Serabek, Kecamatan \\
& Teluk Keramat, Kabupaten Sambas. Metode \\
& pengabdian masyarakat yang digunakan \\
Kata Kunci: body & adalah pelatihan dan penyuluhan. Kegiatan \\
condition score, & pelatihan meliputi manajemen pakan, \\
pelatihan, manajemen & pelatihan cara pembuatan dan pemberian \\
pakan, urea molases & UMB (urea molases block). Metode \\
block, & penyuluhan pelaksanaan pengabdian \\
& masyarakat melalui tatap muka, bimbingan \\
& teknis, dan pendampingan dengan kelompok \\
& ternak di demplot UPSUS SIWAB desa \\
& Sungai Serabek Kecamatan Teluk Keramat \\
& Kabupaten Sambas. Hasil kegiatan \\
& pengabdian masyarakat ini telah dapat \\
& meningkatkan pengetahuan dan keterampilan \\
& kelompok ternak di Desa Sungai Serabek \\
& dalam melakukan perbaikan manajemen \\
& pakan, mengukur BCS, dan ketrampilan \\
& membuat pakan dalam pembuatan UMB. \\
& Adanya penambahan UMB dalam pakan dapat \\
& meningkatkan BCS sapi yang ada di desa \\
& Sungai Serabek, Kecamatan Teluk Keramat, \\
& Kabupaten Sambas. \\
\hline
\end{tabular}




\section{Pendahuluan}

Kabupaten Sambas merupakan salah satu Kabupaten yang terpilih sebagai daerah pendampingan UPSUS SIWAB (Upaya Khusus Sapi Indukan Wajib Bunting) oleh mahasiswa dan dosen Prodi Peternakan Fakultas Pertanian Universitas Tanjungpura khususnya di Kecamatan Teluk Keramat adalah wilayah sentral sapi terbanyak. Luas Kecamatan Teluk Keramat adalah $525,38 \mathrm{~km} 2$. Kecamatan Teluk Keramat pada tahun 2014 terbagi menjadi 24 Desa atau berkurang 7 desa dari tahun 2005 karena pada tahun 2006, tujuh desa di Teluk Keramat membentuk Kecamatan baru yaitu Kecamatan Tangaran. Desa terluas adalah Desa Sekura dengan luas 46,58 km2 atau 8,87 persen sedangkan yang terkecil adalah Desa Pedada denagan luas4,00 km2 atau 0,76 persen dari luas wilayah Kecamatan Teluk Keramat (BPS Sambas, 2020).

Dari kondisi tersebut di atas, pihak pemerintah setempat terus melakukan berbagai upaya dalam mengakomodasi permintaan pasar, penambahan populasi dan perbaikan sistem pemeliharaan terus diintroduksi dan dikembangkan dalam kelembagaan peternak. Populasi sapi potong di Desa Sungai Serabek yang telah di data oleh pendamping UPSUS SIWAB sebanyak 115 ekor, yang terdiri atas induk betina sebanyak 74 ekor, induk jantan sebanyak 12 ekor, pedet betina sebanyak 22 ekor, pedet jantan sebanyak 7 ekor, dan indukan yang mengalami gangguan reproduksi sebanyak 6 ekor dengan BCS rata-rata adalah 2 (dua). Faktor keberhasilan Inseminasi Buatan pada sapi salah satunya tergantung pada penampilan reproduksi pada sapi betina. Penampilan reproduksi yang kurang baik sangat berkaitan dengan BCS (body condition score) yang berada di bawah nilai standar.

Usaha peternakan sapi yang dijalankan oleh masyarakat di Teluk Keramat Kabupaten Sambas umumnya merupakan usaha yang masih berorientasi usaha sampingan hanya sebagai tabungan dan skala kepemilikan ternak sapi hanya skala rumah tangga dengan populasi sapi masing masing 
peternak sekitar 1 - 4 ekor. Tujuan usaha peternakan sapi hanya sebagai usaha sampingan, sehingga terlihat kurus-kurus.

Pakan yang diberikan oleh peternak masih mengandalkan rumput saja sebagai pakan sehingga melihat hal tersebut jelas sapi ini mengalami kekurangan gizi. Dalam meningkatkan suatu gizi dan BCS sapi dilakukanlah penambahan UMB (urea molases block) pada makanannya. UMB (urea molases block) merupakan bahan pemacu, artinya bahwa suplemen ini merupakan jenis pakan yang berperan sebagai pemacu pertumbuhan dan peningkatan populasi mikroba didalam rumen. Pakan pemicu ini dapat merangsang ternak ruminansia dalam menambah jumlah konsumsi serat kasar sehingga meningkatkan produksi.

Berdasarkan permasalahan di atas, program pengabdian masyarakat ini bertujuan untuk memperbaiki manajemen pakan dan memperbaiki BCS (body condition score) ternak sapi di demplot UPSUS SIWAB Desa Sungai Serabek, Kecamatan Teluk Keramat, Kabupaten Sambas.

\section{Metode}

Kegiatan ini dilaksanakan selama empat bulan di Desa Sungai Serabek, Kecamatan Teluk Keramat, Kabupaten Sambas. Program pengabdian masyarakat ini menggunakan pelatihan dan penyuluhan. Berdasarkan program kegiatan pelatihan meliputi manajemen pakan, pelatihan cara pembuatan dan pemberian UMB (urea molases block). Frekuensi masingmasing kegiatan pelatihan membuat UMB (urea molases block) dilakukan selama 3 kali, yaitu diawali dengan penyampaian materi, dilanjutkan dengan praktek langsung, dan pendampingan oleh mahasiswa selama kegiatan berlangsung. Peserta pelatihan adalah peternak pemilik sapi dengan jumlah sapi 74 ekor berasal dari kelompok ternak di Desa Sungai Serabek.

Metode penyuluhan pelaksanaan program pengabdian masyarakat melalui tatap muka, pembimbingan, dan pendampingan dengan kelompok ternak. Sosialisasi program dilakukan dengan tatap muka untuk 
menyampaikan program kegiatan pengabdian masyarakat kepada kelompok sasaran. Kegiatan pelatihan dilakukan dengan sistem praktik di demplot UPSUS SIWAB ternak sapi. Praktik pembuatan UMB (urea molases block) dilakukan secara langsung bersama kelompok ternak, persiapan bahan dan peralatan serta tempat.

Pendampingan dilakukan mulai dari kegiatan pengukuran BCS (body condition score), dan pembuatan UMB (urea molases block). Pembimbingan dilakukan dengan membimbing secara langsung kegiatan pembuatan UMB (urea molases block) secara rutin dalam 4 bulan. Pendampingan dilakukan oleh dosen dan mahasiswa dalam melakukan pembuatan UMB (urea molases block) serta bantuan teknis manajemen pakan di lokasi Demplot UPSUS SIWAB Desa Sungai Serabek, Kecamatan Teluk Keramat, Kabupaten Sambas.

Dalam kegiatan ini, kelompok ternak sebagai mitra kegiatan ini berpartisipasi aktif selama pelatihan, persiapan sampai pelaksanaan manajemen pakan di demplot yang berjalan selama empat bulan. Bentuk partisipasi lain adalah mempersiapkan peralatan, tempat, dan tenaga untuk pelaksanaan kegiatan pembuatan UMB (urea molases block). Alat-alat yang digunakan dalam pelatihan berupa kuali besar, kuali kecil, spatula, cetakan, baskom, timbangan, tungku, kompor gas, dedak padi, bungkil kelapa, ampas tahu, tepung sagu, molases atau gula merah, premik, garam, urea, EM4, dan air.

Bahan-bahan pembuatan UMB (urea molases block) sebanyak $10 \mathrm{~kg}$ adalah sebagai berikut: dedak padi $15 \%=1,5 \mathrm{~kg}$, bungkil kelapa $25 \%=2,5 \mathrm{~kg}$, ampas tahu $25 \%=2,5 \mathrm{~kg}$, tepung sagu $27 \%=2,7 \mathrm{~kg}$, molases atau gula merah $5 \%=0,5 \mathrm{~kg}$, premik $1 \%=1 \mathrm{ons}$, garam $1 \%=1$ ons, urea $1 \%=1$ ons, EM $4=$ 2 tutup botol EM4, dan air = 1 ember kecil. Campur semua bahan ke dalam baskom kecuali gula merah karena proses penambahan gula merah dilakukan dalam bentuk cair tidak berupa padat. Tungku dan kuali besar untuk memasak semua bahan. Selanjutnya masak air sebanyak 1 ember kecil hingga mendidih. 
Masukan semua bahan yang ada di dalam baskom ke dalam kuali besar, aduk semua bahan hingga tercampur rata dan hingga kadar airnya berkurang.

Kadar air yang diperlukan adalah kurang dari 0,3\% agar mikroba tidak beraktivitas karena mikroorganisme dapat menyebabkan timbulnya jamur yang membuat UMB (urea molases block) tidak tahan lama. Gula merah yang sudah cair diberikan pada tahap terakhir dan di masak bersamaan dengan bahan yang ada di kuali besar hingga setengah mengeras. Setelah itu kuali besar diangkat dari tungku, kemudian masukan gula merah dan aduk semua bahan di dalam kuali besar hingga tercampur rata. Terakhir cetak UMB (urea molases block) ke dalam cetakan dan keringkan di bawah sinar matahari.

Setelah selesai kegiatan program pengabdian kepada masyarakat, kelompok ternak juga berkewajiban mengelola sarana dan prasarana yang telah diberikan serta mengembangkan usaha agar memberikan manfaat terhadap peningkatan pendapatan kelompok ternak dan masyarakat sekitar.

\section{Hasil dan Pembahasan}

Hasil pelaksanaan program pengabdian masyarakat telah berhasil mencapai target dan dapat meningkatkan pengetahuan dan keterampilan kelompok ternak di Desa Sungai Serabek dalam melakukan perbaikan manajemen pakan, pembuatan pakan UMB, dan pemberian pakan UMB. Sebelum sapi diberi UMB (urea molases block) terlebih dahulu dilakukan pengukuran pada lingkar dada, panjang badan, dan tinggi badan sapi.

Pada pembuatan UMB (urea molases block) ini digunakan bahan yang mudah diperoleh oleh peternak yang berasal dari daerah sekitar Sungai Serabek, seperti dedak padi, bungkil kelapa, ampas tahu, tepung sagu, molases, premik, garam, urea, EM4, dan air. Pelaksanaan pelatihan yang telah dilakukan di demplot ternak sapi di desa Sungai Serabek Kecamatan Teluk Keramat Kabupaten Sambas tertera pada Gambar 1. 


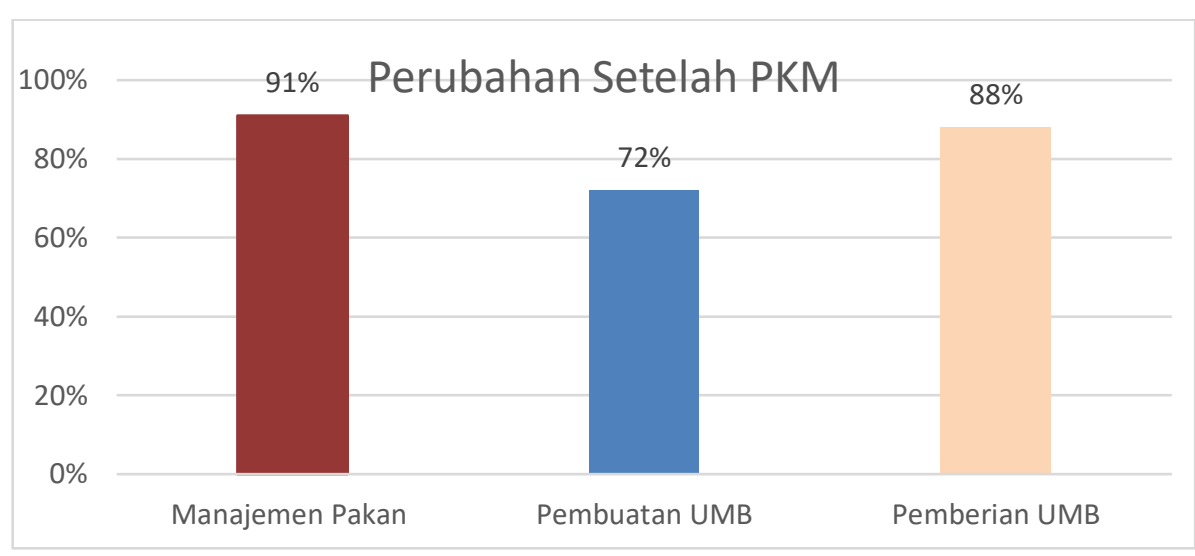

Gambar 1. Perubahan Pengetahuan Setelah PKM

Peternak di lokasi demplot UPSUS SIWAB setelah melakukan pelatihan telah melakukan perbaikan manajemen pakan ternak sapi dengan angka 91\%. Hal ini menunjukkan peternak bisa memahami dengan baik manajemen pakan sapi seperti melakukan perbaikan waktu pemberian pakan, penanganan pakan sebelum diberikan ke ternak sapi, kompisisi hijuan dan konsentrat (Afriani, et. al., 2019). Pada pelatihan pembuatan Urea Molases Blok (UMB) dapat dipahami oleh peternak sebanyak 72\% karena bahan-bahan pakan UMB mudah dimengerti dan didapatkan di daerah Teluk Keramat. Program pelatihan pemberian UMB setelah tercetak maka dilakukan pemberiaan UMB ke ternak sapi dapat diterakan dengan baik oleh peternak di lokasi demplot UPSUS SIWAB dengan angka $88 \%$. Pelaksanaan pelatihan manajemen pakan, pembuatan UMB dan pemberian UMB secara umum mampu dimengerti dan dilakukan dengan baik oleh peternak sapi di Desa Sungai Serabek, Kecamatan Teluk Keramat, Kabupaten Sambas.

Beberapa perhatian dalam melaksanakan program sebelum dan sesudah berjalannya pembuatan UMB (urea molases block) antara lain: Konsumsi Pakan. Konsumsi pakan harian setiap satu ekor sapi adalah 10\% dari berat badan, bentuk pakan yang diberikan berupa hijauan dan UMB yang 
setiap sapi diberi sebanyak 1,5 ons dalam satu hari dan pemberian dilakukan pagi dan sore. UMB yang telah diberikan ke sapi, dalam waktu singkat UMB tersebut habis dimakan oleh sapi. Dengan menambahkan UMB ke dalam pakan tersebut sapi milik masyarakat mengalami peningkatan nafsu makan, leleran hidung yang cair telah normal kembali, dan kadang ternak menjadi sangat jinak karena telah mencium bau harum dari UMB yang di bawa oleh peternak di demplot UPSUS SIWAB.

Koversi Pakan. Bahwa dengan pemberian UMB memberikan pengaruh lebih baik terhadap kenaikkan berat badan dibandingkan dengan hanya pemberian rumput lapang. Setelah data tersebut dihitung bahwa nilai rata-rata konversi pakan sapi milik masyarakat adalah sebesar 45,24. Konversi pakan sangat dipengaruhi oleh kondisi ternak, daya cerna ternak, jenis kelamin, bangsa, kualitas dan kuantitas pakan, juga faktor lingkungan (Setiawan, 2018).

Income Over Feed Cost (IOFC). Merupakan selisih antara penerimaan dengan biaya pakan. Penerimaan merupakan perkalian antara produksi peternakan atau PBBH dengan harga jual, sedangkan biaya pakan adalah biaya yang dikeluarkan untuk menghasilkan pertambahan bobot badan ternak (Prasetiyo, 2013). Perhitungan IOFC dilakukan untuk mengetahui nilai ekonomis pakan terhadap pendapatan kelompok ternak sapi potong agar hasil yang diperoleh dalam program pengabdian masyarakat pembuatan demplot UPSUS SIWAB ternak sapi dapat aplikasikan ke kelompok ternak.

$$
\begin{aligned}
\text { IOFC } & =\text { Penerimaan }- \text { Biaya pakan } \\
& =(0,54 \times 60.000)-(15.000+939) \\
& =32.400-15.939 \\
& =15.461
\end{aligned}
$$


Dari hasil perhitungan yang didapat bahwa Income over feed cost sapi milik masyarakat yang diberi UMB (urea molases block) adalah sebesar Rp 15.461/ekor/hari. Hal yang dapat mempengaruhi IOFC adalah harga pakan, PBBH, dan efisiensi pakan (Setiawan dan Nuraini, 2016). Tingginya harga jual sapi juga mempengaruhi IOFC, oleh karena itu di daerah Sambas sangat mendukung untuk beternak sapi. Langkah selanjutnya dalam proses pembuatan UMB (urea molases block) ini adalah timbang semua bahan-bahan utama untuk membuat UMB terlebih dahulu seperti tertera pada Gambar 2.
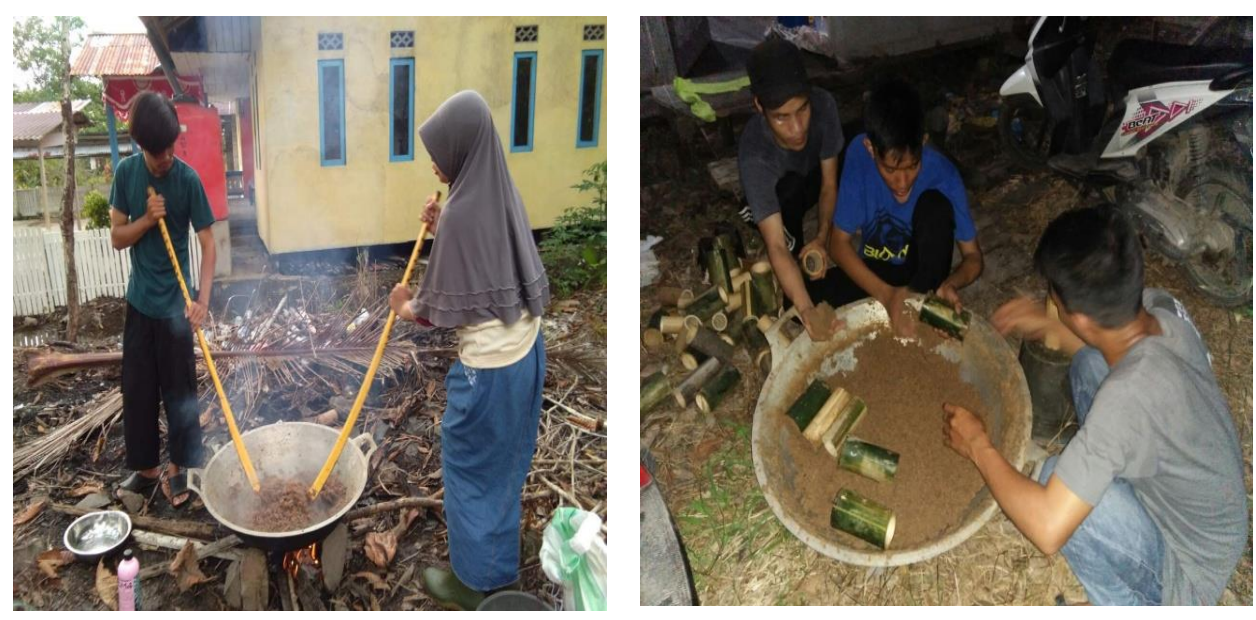

Gambar 2. Masak Bersama

Dalam memberikan UMB (urea molases block) yang telah jadi adalah dengan cara meletakkan di bagian kandang ternak yang mudah dijangkau dan dekatnya posisi berdiri sapi tersebut. Dalam 1 hari diberikan sebanyak 2 kali yaitu pagi dan sore sebanyak 1,5 ons. Dari data diatas bahwa demplot yang dilakukan berlangsung kurang lebih 1 bulan dan telah didapat rata-rata pertambahan berat badan harian seekor sapi adalah $0,54 \mathrm{~kg}$. 


\section{Kesimpulan}

Hasil kegiatan pengabdian masyarakat ini telah dapat meningkatkan pengetahuan dan keterampilan kelompok ternak di Desa Sungai Serabek dalam melakukan perbaikan manajemen pakan dan peningkatan BCS. Adanya demplot dengan menambahkan UMB dalam pakan upaya peningkatan sapi indukan wajib bunting dapat membantu masyarakat dalam meningkatkan produktivitas ternaknya. Luaran program pengabdian masyarakat yang dihasilkan adalah pemberian UMB (urea molases block) dapat meningkatkan pertambahan berat badan harian sapi dengan rata-rata adalah $0,54 \mathrm{~kg} / \mathrm{ekor}$.

\section{Daftar Referensi}

Afriani, T., F.L. Syaiful dan Y. Seftiadi. 2019. Pemberdayaan Masyarakat Melalui Pelatihan Pembuatan Pakan Alternatif Amoniasi Jerami Jagung Dinagari Pelangai Kaciak Kecamatan Ranah Pesisir Pesisir Selatan. Jurnal Hilirisasi IPTEKS 2(2): 122-129.

Diakses dari https://doi.org/10.25077/jhi.v2i2.244.

Anwar, S; Madariza, F dan Anas, A. 2009. Ilmu Penyuluhan Pertanian. Universitas Andalas, Padang.

BPS Kabupaten Sambas. 2020. Kabupaten Sambas Dalam Angka. Sambas.

Ediset, E heriyanto, dan A Anas. 2018. Perbaikan Usaha Peternakan Sapi Pada Aspek Pakan Di Nagari Siguntur, Kecamatan Sitiung, Dharmasraya. Buletin Ilmiah Nagari membangun 1(4): 139-145. Diakses dari https://doi.org/10.25077/buletin\%20ilmiah\%20nagari\%20membangun. v1i4.53

Nista, D., Natalia H, Taufik A. 2010. Teknologi Pengolahan Pakan. Palembang. Direktorat Jendral Bina Produksi Peternakan. Hlm. 2-3.

Salman, Y Anggriani, E.D. Sulistyowati, dan H.S. Tira. 2020. Penyuluhan Pembuatan Urea Molasses Block (UMB) Sebagai Pakan Supplement Untuk Ternak Ruminansia. Jurnal Karya Pengabdian 2(2): 100-104.

Diaksesdarihttp://www.jkp.unram.ac.id/index.php/JKP/article/view/65/ 
pdf

Setiawan, D. 2012. Performance of Ongole Grade Cattle Fed Mulberry Leave Meal Combined with Different Concentrates. Tesis. Institut Pertanian Bogor. Bogor. Diakses dari https://repository.ipb.ac.id/bitstream/handle/123456789/57310/2012ds e.pdf? sequence $=1 \&$ is Allowed $=$.

Setiawan, D. 2018. Artificial Insemination of Beef Cattle UPSUS SIWAB Program Based on the Calculation of Non-Return Rate, Service Per Conception and Calving Rate In The North Kayong Regency. The International Journal Tropical Veterinary and Biomedical Research 3(1): 7-11

Diakses dari https://doi.org/10.21157/ijtvbr.v3i1.11339

Setiawan, D. dan H.Nuraini. 2016. Penampilan Produksi Sapi Peranakan

Ongole yang Diberi Pakan Konsentrat yang Mengandung Tepung Daun Murbei. Jurnal Agripet 16(1): 16-22.

Diakses dari https://doi.org/10.17969/agripet.v16i1.3013

Syaiful, F.L., U.G.S. Dinata dan F. Ferido. 2018. Pemberdayaan Masyarakat Nagari Sontang Kabupaten Pasaman Melalui Inovasi Budidaya Sapi Potong Dan Inovasi Pakan Alternatif Yang Ramah Lingkungan. Buletin Ilmiah Nagari Membangun. 1(3) : 21-31.Diakses dari https://doi.org/10.25077/buletin\%20ilmiah\%20nagari\%20membangun. v1i3.25.

Tika, W.R. 2017. Pengaruh Pemberian Herbal Urea Moasses Blok Terhadap Kecernaan Bahan Kering, Bahan Organik Dan Protein Kasar Pada Sapi Potong. Diploma Thesis, Universitas Andalas.

Zakiatulyaqin, I Suswanto, RB Lestari, D Setiawan, dan AMS Munir. 2017. Income Over Feed Cost Dan RC Ratio Usaha Ternak Sapi Melalui Pemanfaatan Limbah Kelapa Sawit. Jurnal Ilmiah Peternakan Terpadu 5(1): 18-22. Diakses dari http://dx.doi.org/10.23960/jipt.v5i1.p18-22 